\title{
Handwashing With a Water-Efficient Tap and Low-Cost Foaming Soap: The Povu Poa "Cool Foam" System in Kenya
}

\author{
Jaynie Whinnery, ${ }^{a}$ Gauthami Penakalapati, ${ }^{a}$ Rachel Steinacher, ${ }^{a}$ Noel Wilson, ${ }^{b}$ Clair Null, ${ }^{a}$ \\ Amy J Pickering ${ }^{c}$
}

\begin{abstract}
The new handwashing system, designed with end user input, features an economical foaming soap dispenser and a hygienic, water-efficient tap for use in household and institutional settings that lack reliable access to piped water. Cost of the soap and water needed for use is less than US\$0.10 per 100 handwash uses, compared with US\$0.20-\$0.44 for conventional handwashing stations used in Kenya.
\end{abstract}

$\mathbf{U}$ sing an interactive and iterative design approach involving representative end users, we created a new handwashing system in Kisumu, Kenya, to make handwashing convenient and economical in areas without reliable piped water. The innovative and adaptable system, branded as Povu Poa ("Cool Foam" in Kiswahili), integrates a cost-effective foaming soap dispenser with a hygienic, water-frugal water tap in a secure and affordable design.

\section{BACKGROUND}

Handwashing with soap and water reduces the spread of respiratory and diarrheal disease, the 2 leading causes of death in children under 5 years old. ${ }^{1-5}$ Studies estimate that handwashing with soap can reduce acute respiratory infections by $21 \%$ and the risk of diarrhea by $40 \%{ }^{6,7}$

In settings without piped water, refilling water containers and securing soap for handwashing requires constant user effort and expense, creating barriers to handwashing with soap. In Kenya, for example, 78\% of the population lacks access to household piped water, ${ }^{8}$ and the prevalence of handwashing with soap after contact with feces is estimated to be $15 \%{ }^{6}$

People are more likely to wash their hands at critical times if they have a dedicated place with soap and

\footnotetext{
a Innovations for Poverty Action, Kenya, Kisumu, Kenya.

${ }^{b}$ Catapult Design, San Francisco, CA, USA.

'Stanford University, Stanford Center for Innovation in Global Health, Stanford, CA, USA.

Correspondence to Amy J Pickering (amyjanel@gmail.com).
}

water. ${ }^{9}$ Conventional handwashing stations in Kenya, such as a jug and basin (Figure lA) or a bucket with a tap (Figure 1B), are prone to soap theft, are cumbersome and unhygienic, and are not water-efficient. Alternative handwashing systems aim to provide affordable, water-efficient, and dedicated locations for handwashing. For example, the "leaky tin" dispenses water from a hole near the base of a container when a person removes a plug, and the "tippy tap" dispenses water by tipping the container when a person pulls on the attached string lever or steps on a foot pedal. However, difficulties with soap provision and security remain. The dual tippy tap integrates separate containers for soapy water and rinse water into a single system to address these issues (Figure 1C). ${ }^{10}$ The soapy water mixture, a 50:1 water-to-powdered soap ratio, increases the lifetime of the soap and is an effective cleansing agent. $^{11}$ Still, the dual tippy tap has several shortcomings: it can become unstable over time, it requires frequent maintenance, the metal components are prone to theft, and the hardware is not particularly attractive.

\section{INNOVATION PROCESS}

We began our design process by conducting in-depth interviews and focus group discussions with potential users in low-income, peri-urban areas of Kisumu, including household members in 5 households, students and teachers in 3 primary schools, and health care workers in 2 clinics. Users preferred hand washing systems that were easy to operate and refill with water, a tap that allowed them to control the flow of water, and a portable unit that they could store inside 
FIGURE 1. Conventional Handwashing Stations in Kenya

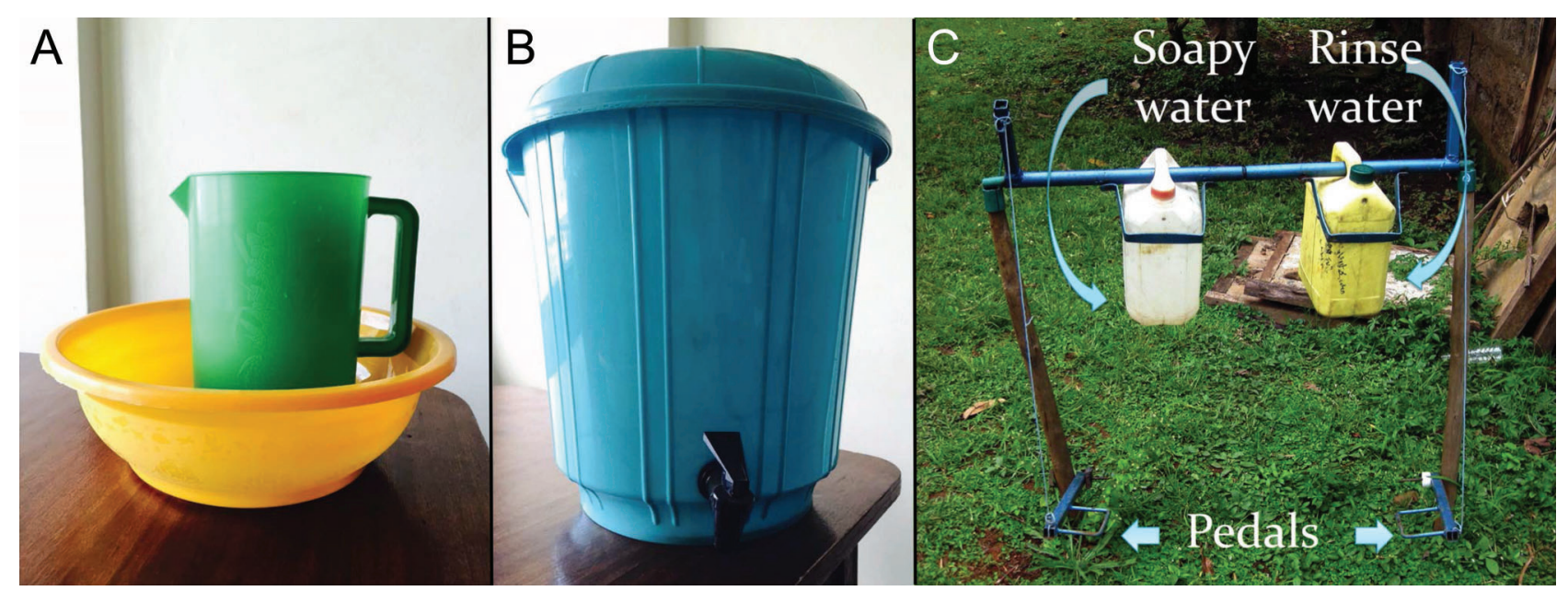

(A) jug and basin; (B) bucket with a tap; (C) dual tippy tap that dispenses soapy water and plain water.

their home or institutions at night to prevent theft. We then created a series of handwashing system prototypes in response to user needs and iteratively developed the designs with multiple rounds of input from end users based on their experiences testing the various features.

After multiple rounds of user-focused testing with various handwashing components and systems, the final product we developed was a desirable, robust, affordable, and water-frugal system that integrates a secure soap dispenser with rinse water. We developed 2 configurations of the system, both of which are currently marketed under the brand Povu Poa ("Cool Foam" in Swahili).

- The Povu Poa bucket model is composed of two 20-liter buckets stacked vertically, which can be set on any level surface and easily disassembled for transport and security (Figure 2A).

- The Povu Poa pipe model is a light, highly portable 5-liter pipe that can be hung from a wall, fencepost, tree, or other standing structure and that can be plumbed to larger water tanks and drainage systems (Figure 2B).

Both Povu Poa models integrate the waterfrugal swing tap to dispense water (Figure 3A) and the accordion soap foamer that mixes soapy water with air to create a foam (Figure 3B). Runoff water from handwashing collects in the lower bucket for the bucket model or a separate basin for the pipe model (not shown).

\section{KEY PRODUCT FEATURES OF THE POVU POA HANDWASHING SYSTEM}

- Soap security: The soap foamer is attached to the system, preventing theft.

- Affordability: Just $5 \mathrm{~g}$ of powdered or liquid soap mixed with $250 \mathrm{~mL}$ of water can provide 100 uses for US\$0.10 (cost includes soap and water).

- Hygienic: The innovative swing-tap design is bidirectional and can be used with the back of The handwashing the hand or wrist, limiting recontamination of system we hands after handwashing.

- Water-frugality: The water flow is sufficient for handwashing while providing a 30-77\% reduction in water usage compared with conventional methods.

- Scalability: Components are specifically designed for low-cost mass production and deployment, estimated at US\$12 per unit.

- Adaptable: The 2 handwashing station configurations can be adapted to meet different
$78 \%$ of the population in

Kenya lacks access to household piped water, creating barriers to handwashing with soap.

developed, marketed under the brand Povu Poa, comes in 2 configurations: a bucket and a pipe model. 
FIGURE 2. Configurations of the Povu Poa Handwashing System

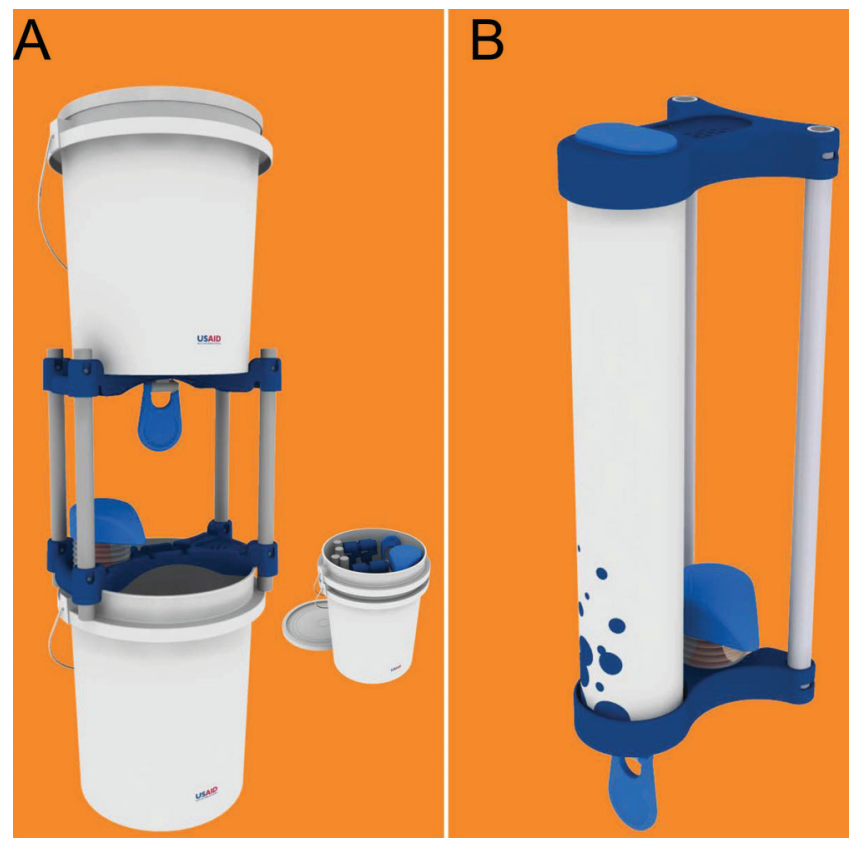

(A) bucket model design; (B) pipe model design.

The Povu Poa system uses $30 \%-77 \%$ less water than conventional handwashing stations used in Kenya.

The Povu Poa pipe model would pay for itself in about 2.5 years for $a$ family of 5 . needs and preferences (Figure 4) and can be used in households and institutional settings, such as schools and health centers.

\section{SOAP AND WATER EFFICIENCY TESTING}

We tested the water and the soap efficiency of the Povu Poa pipe and bucket prototypes alongside 6 handwashing systems commonly used in Kenya, such as the dual tippy tap and a jug and basin. At the beginning of each test, the system being evaluated was filled to capacity with water. For each test, research assistants from Innovations for Poverty Action washed their hands with soap and water for 20 seconds. Handwashing events continued intermittently until the water reservoir was empty. The total volume of water and handwash count were used to calculate water quantity per use. Before and after weights of the soap were used to calculate the amount of soap per use. Actual soap costs were used along with user-provided water prices.
The Povu Poa systems used 30\% to 77\% less water compared with the conventional systems tested, providing approximately 14 to 15 uses per 5 liters of water compared with 4 to 10 uses from the other systems (Table). The Povu Poa systems also used $94 \%$ to $99 \%$ less soap than the other tested systems, providing approximately 15,000 uses per US\$1 spent on soap compared with approximately 500 to 1,600 uses with conventional systems. Overall the cost for soap and water with the Povu Poa is less than US\$0.10 per 100 uses, compared with US\$0.20 to US\$0.44 per 100 uses for other systems tested. The waterfrugal tap provides approximately 60 and 14 uses between refills for the bucket and pipe model, respectively.

Based on these results and our estimated mass production cost of US\$12 for the Povu Poa pipe model, the pipe model would pay for itself in approximately 2.5 years for a family of 5 who each wash their hands 3 times per day using a jug and basin. When considering the soap foamer alone, at a mass production price of US\$3, the 
FIGURE 3. Water- and Soap-Dispensing Elements of the Povu Poa Handwashing System
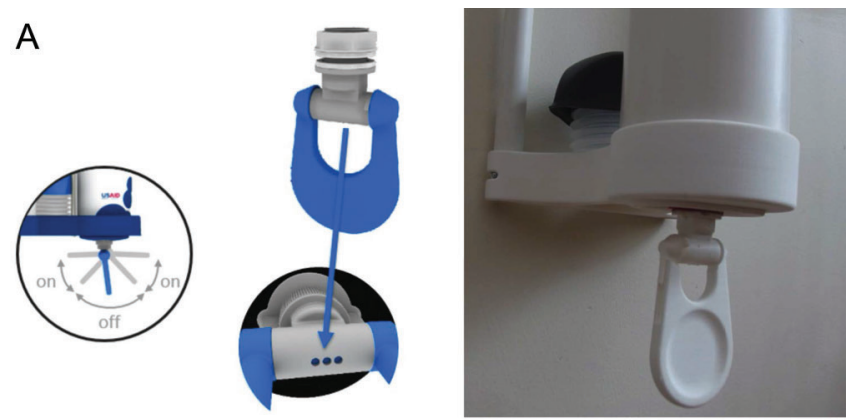

B
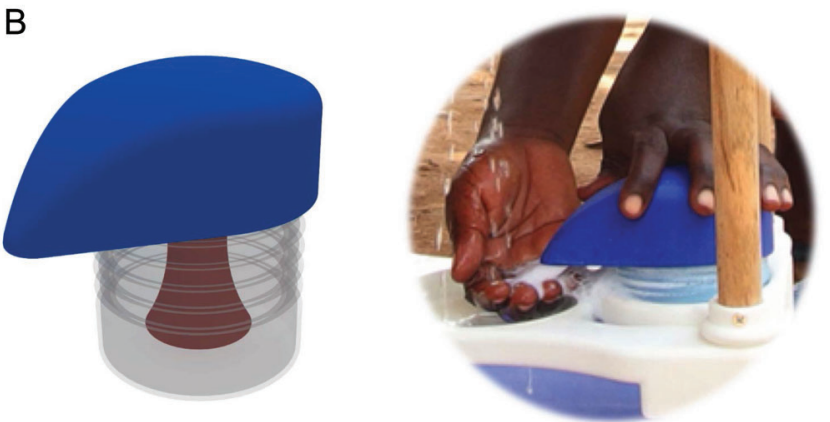

(A) Users can operate the Povu Poa Swing Tap hygienically with the back of their hand. The swing tap dispenses water from up to 3 holes; users can control the amount and flow of water coming from these holes based on how far forward or backward they pull/push the tap. (B) The Povu Poa Soap Foamer creates foam by mixing soapy water and air.

FIGURE 4. Potential Adaptations to the Povu Poa Handwashing System
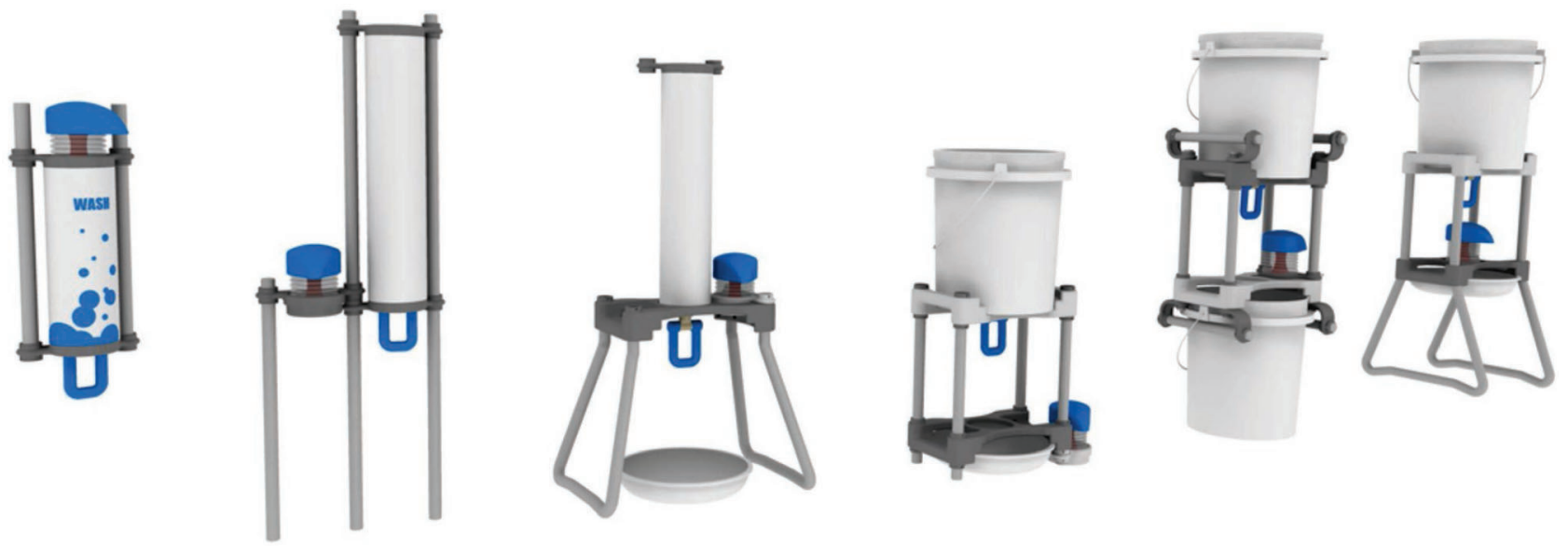
TABLE. Water and Soap Efficiency for the Povu Poa Handwashing Prototypes Compared With Other Handwashing Devices

\begin{tabular}{|c|c|c|c|c|c|c|c|}
\hline & Soap Type & $\begin{array}{l}\text { Water } \\
\text { Quantity } \\
\text { per Use } \\
\text { (mL) }\end{array}$ & $\begin{array}{l}\text { No. of } \\
\text { Uses per } \\
5 \mathrm{~L} \text { of } \\
\text { Water }\end{array}$ & $\begin{array}{l}\text { No. of Uses } \\
\text { per US\$1 } \\
\text { Spent on } \\
\text { Water }\end{array}$ & $\begin{array}{c}\text { Amount } \\
\text { of Soap } \\
\text { per Use } \\
\text { (g) }\end{array}$ & $\begin{array}{l}\text { No. of Uses } \\
\text { per US\$1 } \\
\text { Spent on } \\
\text { Soap }\end{array}$ & $\begin{array}{l}\text { Cost in US\$ for } \\
\text { Soap and Water } \\
\text { per } 100 \text { Uses }\end{array}$ \\
\hline $\begin{array}{l}\text { Povu Poa pipe } \\
\text { model }\end{array}$ & $\begin{array}{l}\text { Soapy water made with } \\
\text { Omo brand powdered } \\
\text { soap }\end{array}$ & 357 & 14 & 1,064 & 0.03 & 14,865 & $\$ 0.10$ \\
\hline $\begin{array}{l}\text { Povu Poa bucket } \\
\text { model }\end{array}$ & $\begin{array}{l}\text { Soapy water made with } \\
\text { Omo brand powdered } \\
\text { soap }\end{array}$ & 333 & 15 & 1,140 & 0.03 & 15,696 & $\$ 0.09$ \\
\hline Dual tippy tap & $\begin{array}{l}\text { Soapy water made with } \\
\text { Omo brand powdered } \\
\text { soap }\end{array}$ & 625 & 8 & 608 & 0.96 & 500 & $\$ 0.37$ \\
\hline Jug and basin & $\begin{array}{l}\text { Multipurpose bar soap } \\
\text { (Toyo brand) }\end{array}$ & 513 & 10 & 741 & 0.49 & 1,600 & $\$ 0.20$ \\
\hline Sink with metal tap & $\begin{array}{l}\text { Multipurpose bar soap } \\
\text { (Toyo brand) }\end{array}$ & 1,429 & 4 & 266 & 0.71 & 1,100 & $\$ 0.47$ \\
\hline $\begin{array}{l}20 \mathrm{~L} \text { barrel with } \\
\text { metal tap }\end{array}$ & Locally made liquid soap & 690 & 7 & 551 & 1.90 & 800 & $\$ 0.30$ \\
\hline $\begin{array}{l}20 \mathrm{~L} \text { barrel with } \\
\text { plastic tap }\end{array}$ & Locally made liquid soap & 1,000 & 5 & 380 & 2.85 & 550 & $\$ 0.44$ \\
\hline $\begin{array}{l}15 \mathrm{~L} \text { bucket with } \\
\text { plastic tap }\end{array}$ & $\begin{array}{l}\text { Multipurpose bar soap } \\
\text { (Toyo brand) }\end{array}$ & 833 & 6 & 456 & 0.89 & 900 & $\$ 0.33$ \\
\hline
\end{tabular}

soap foamer would pay for itself in just 1 year using the same assumptions and the calculated cost savings of soap.

\section{CURRENT AND FUTURE WORK}

We have produced In focus group discussions, approximately $80 \%$ of 200 Povu Poa systems in Kenya and are currently field testing them in several locations. participants stated they would purchase a Povu Poa product, suggesting the aspirational value of the product. We have produced 200 Povu Poa systems in Kenya and are currently field testing them in peri-urban households, schools, and health clinics to assess long-term usage (up to 1 year of evaluation) and durability. To assess demand for the product, Povu Poa units are currently being sold to households at randomized price points, ranging from US\$1 to US\$12, to determine the price that most low-income users are willing and able to pay. Next steps include finalizing the design for mass production of the Povu Poa system, partnering with a plastics manufacturer, and identifying effective sales and distribution strategies.

Acknowledgments: This manuscript was made possible by the generous support of the American people through the United States Agency for International Development (USAID). The contents are the responsibility of the authors and do not necessarily reflect the views of USAID or the United States Government. We would like to thank Jemima Akinyi Okal for excellent fieldwork assistance and Pavani Ram for input on the design process.

Competing Interests: None declared.

\section{REFERENCES}

1. Bhutta ZA, Das JK, Walker N, Rizvi A, Campbell H, Rudan I, et al. Interventions to address deaths from childhood pneumonia and diarrhoea equitably: what works and at what cost? Lancet. 2013;381(9875):1417-1429. CrossRef. Medline

2. Bowen A, Agboatwalla M, Luby S, Tobery T, Ayers T, Hoekstra RM. Association between intensive handwashing promotion and child development in Karachi, Pakistan: a cluster randomized controlled trial. Arch Pediatr Adolesc Med. 2012;166(11):10371044. CrossRef. Medline 
3. Curtis V, Cairncross S. Effect of washing hands with soap on diarrhoea risk in the community: a systematic review. Lancet Infect Dis. 2003;3(5):275-281. CrossRef. Medline

4. Rabie T, Curtis V. Handwashing and risk of respiratory infections: a quantitative systematic review. Trop Med Int Health. 2006; 11 (3):258-267. CrossRef. Medline

5. Walker CL, Rudan I, Liu L, Nair H, Theodoratou E, Bhutta ZA, et al. Global burden of childhood pneumonia and diarrhoea. Lancet. 2013;381(9875):1405-1416. CrossRef. Medline

6. Freeman MC, Stocks ME, Cumming O, Jeandron A, Higgins JP, Wolf $\mathrm{J}$, et al. Hygiene and health: systematic review of handwashing practices worldwide and update of health effects. Trop Med Int Health. 2014;19(8):906-916. CrossRef. Medline

7. Aiello AE, Coulborn RM, Perez V, Larson EL. Effect of hand hygiene on infectious disease risk in the community setting: a meta-analysis. Am J Public Health. 2008;98(8):1372-1381. CrossRef. Medline

8. United Nations Children's Fund (UNICEF); World Health Organization (WHO). Progress on sanitation and drinking water:
2015 update and MDG assessment. New York: UNICEF; 2015. Co-published by WHO . Available from: http://www.unicef.org/ publications/files/Progress_on_Sanitation_and_Drinking_ Water_2015_Update_.pdf

9. Luby SP, Haldexsr AK, Tronchet C, Akhter S, Bhuiya A, Johnston RB. Household characteristics associated with handwashing with soap in rural Bangladesh. Am J Trop Med Hyg. 2009;81(5):882-887. CrossRef. Medline

10. Arnold BF, Null C, Luby SP, Unicomb L, Stewart CP, Dewey KG, et al. Cluster-randomised controlled trials of individual and combined water, sanitation, hygiene and nutritional interventions in rural Bangladesh and Kenya: the WASH Benefits study design and rationale. BMJ Open. 2013;3(8):e003476. CrossRef. Medline

11. Amin N, Pickering AJ, Ram PK, Unicomb L, Najnin N, Homaira $\mathrm{N}$, et al. Microbiological evaluation of the efficacy of soapy water to clean hands: a randomized, non-inferiority field trial. Am J Trop Med Hyg. 2014;91(2):415-423. CrossRef. Medline

\section{Peer Reviewed}

Received: 2016 Jan 27; Accepted: 2016 May 13

Cite this article as: Whinnery J, Penakalapati G, Steinacher R, Wilson N, Null C, Pickering AJ. Handwashing with a water-efficient tap and low-cost foaming soap: the Povu Poa "Cool Foam" system in Kenya. Glob Health Sci Pract. 2016;4(2):336-341. http://dx.doi.org/10.9745/ GHSP-D-16-00022

(c) Whinnery et al. This is an open-access article distributed under the terms of the Creative Commons Attribution License, which permits unrestricted use, distribution, and reproduction in any medium, provided the original author and source are properly cited. To view a copy of the license, visit http://creativecommons.org/licenses/by/3.0/. When linking to this article, please use the following permanent link: http://dx.doi.org/ 10.9745/GHSP-D-16-00022 